\title{
Experiences from nine passive houses in Sweden - Indoor thermal environment and energy use
}

\author{
Patrik Rohdin, Andreas Molin and Bahram Moshfegh
}

\section{Linköping University Post Print}

\section{Tweet}

N.B.: When citing this work, cite the original article.

Original Publication:

Patrik Rohdin, Andreas Molin and Bahram Moshfegh, Experiences from nine passive houses in Sweden - Indoor thermal environment and energy use, 2014, Building and Environment, (71), 176-185.

http://dx.doi.org/10.1016/j.buildenv.2013.09.017

Copyright: Elsevier http://www.elsevier.com/

Postprint available at: Linköping University Electronic Press http://urn.kb.se/resolve?urn=urn:nbn:se:liu:diva-103277 


\title{
Experiences from nine passive houses in Sweden - indoor thermal environment and energy use
}

\author{
Patrik Rohdin ${ }^{*}$, , Andreas Molin ${ }^{1}$, Bahram Moshfegh ${ }^{1}$ \\ ${ }^{1}$ Division of Energy Systems, Department of Management and Engineering, Linköping University, \\ Sweden.
}

Keywords: Passive house, low-energy building, post-occupancy evaluation, BES, CFD.

\begin{abstract}
This paper presents experiences from a recently built area with passive houses in Linköping, Sweden and compares them with conventional buildings, mainly from an indoor environment perspective, but also based on energy use. The built area consists of 39 recently constructed terraced houses, of which nine are built according to the passive house standard. The aspects of thermal comfort as well as local discomfort are studied. The methodology is based on on-site measurements and two types of simulations - CFD and Building Energy Simulation. In addition a post-occupancy evaluation was made using a standardized questionnaire to relate the occupant's perception of the indoor environment one year after the buildings were completed.

The thermal comfort for these newly built passive houses is well within the limits in the local building code. However, some interesting findings related to local comfort such as cold floors are found in the post-occupancy evaluation as well as in the predictions. The occupants of the passive houses experience cold floors to a higher degree than in the conventional buildings. It was also shown that there are a higher number of complaints related to high temperatures during summer in the passive houses. It is worth noting that the buildings do not have external shading installed by default. The effect of varying temperatures was also observed in the passive houses to a higher degree than in the more conventional buildings, especially related to cooking and other heatgenerating activities, which is normal in a more well insulated and airtight building.
\end{abstract}

\section{Introduction}

Primary energy demand in the world has increased drastically in recent decades. Furthermore, the EU Commission has recently stated that one of its highest priority tasks is to address global warming, with special focus on reducing greenhouse gases. The Commission states in the directive for energy efficiency in the built environment that the building sector must decrease its use of energy to reduce $\mathrm{CO}_{2}$ emissions. In addition the target for energy efficiency within the Union states that a $20 \%$ increase in energy efficiency shall be met by 2020 . In order to meet these targets, many different activities must strive towards the same goal. One major part is the building and service sector, which accounts for about $40 \%$ of total energy use in Sweden. The building performance directive also states that near-zero energy buildings (NZEB) are an important component to achieve these goals. Several established labels for energy-efficient buildings already exist, with passive houses as one well-known type. The passive house concept, according to for example [1], has then been adapted to Swedish conditions and is used by FEBY (Forum for energy-efficient buildings) [2]. FEBY issues certificates and performs validations related to the passive house concept in Sweden. For Nordic conditions the number of studies in 
which post-occupancy evaluations and follow-up studies have been made is still relatively low, but some examples exist, such as for the first passive houses built in Sweden in Lindås in 2001 $[3,4]$. The benefits of evaluating early projects in new climatic areas is apparent as it helps to avoid poor indoor environment conditions and confirms that the energy use is within the limits of what was expected from the building.

The aim of this paper is to present an evaluation and experiences of indoor thermal environment and energy use for nine passive houses built in Linköping, Sweden. The houses are also compared, in terms of indoor thermal environment, to 30 other more conventional buildings built at the same time and in the same area. This comparison is based on a post-occupancy survey.

\section{Object description}

The area consists of 39 terraced houses within the city limits of Linköping. Of these buildings seven have three rooms and kitchen $\left(74 \mathrm{~m}^{2}\right.$ ) and 32 have four rooms and kitchen (about 105-107 $\mathrm{m}^{2}$ ). Of these 39 houses, nine were built according to the passive house standard, seven of which have four rooms and kitchen $\left(105 \mathrm{~m}^{2}\right)$ while two have three rooms and kitchen. The passive house certification was made according to FEBY. The 30 houses that are constructed as nonpassive houses follow the general building code in Sweden (BBR). In Figure 1 a description of the area is shown and the passive houses are marked. One passive building has been selected for detailed measurements, evaluation and comparison. The house has four rooms and kitchen (105 $\mathrm{m}^{2}$ ). Windows mainly face east and west from the buildings and the house is built on a foundation of steel-reinforced concrete with insulation below. The reference about window direction was made mainly to clarify the orientation and explain how the sun influences the buildings. In addition to this a more conventional building was chosen in the same area for comparison. The more conventional building has the same orientation and same type of ground construction but is slightly larger $\left(107 \mathrm{~m}^{2}\right)$. The difference in floor area reflects the difference in insulation thickness of the walls. The basic data for the two different types of buildings are presented in Table 1 . The air-tightness of the building was tested using a blower door system and found to be $0.33 \mathrm{ACH}$ for the passive house construction, which represents an air-tight construction when compared to the national building code. The internal heat gains, such as solar gains, household equipment, lighting, and the heat from the tenant, are a major part of the heat balance for both of the studied buildings. The passive house is heated mainly by these heat gains. The only permanent additional heat source in the passive house is a hydronic heating coil in the compact unit which can heat the supply air. The designed power for the heating coil is $2 \mathrm{~kW}\left(20 \mathrm{~W} / \mathrm{m}^{2}\right)$.

In the non-passive house conventional radiators are used. The set point can be adjusted by the tenant in both cases. The supply and exhaust compact unit with heat exchange supplies a balanced and Constant Air Volume (CAV) in both cases. The temperature efficiency of the heat exchanger is $87 \%$ according to the manufacturer for the passive house and $83 \%$ for the non-passive house. However, tests and an evaluation of the energy aspects of the passive house showed that the actual practical efficiency for the exchanger is $76 \%$ [5], and $78 \%$ for the non-passive house. 


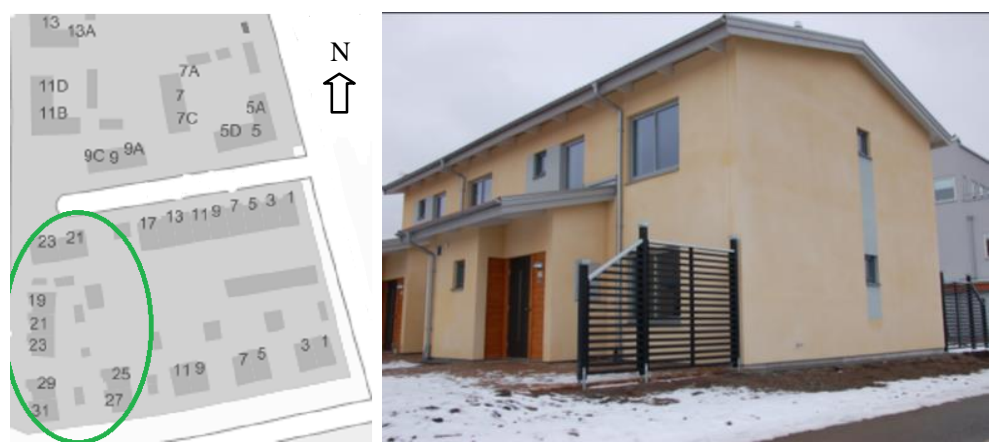

Figure 1. Illustration of the built area. The nine marked houses are passive houses. Right figure, photo of the passive test houses. The test house is marked 27 on the map above.

Table 1. U-values, air-flows, thermal efficiency and cold bridges.

\begin{tabular}{|l|c|c|}
\hline Thermal transmittance $\left(\mathbf{W} / \mathrm{m}^{2}{ }^{\circ} \mathrm{C}\right)$ & Passive house & Conventional house \\
\hline Floor & 0.12 & 0.18 \\
\hline Roof & 0.09 & 0.09 \\
\hline Wall & 0.11 & 0.19 \\
\hline Window & $0.88-1.22$ & $1.12-1.39$ \\
\hline Door & 0.75 & 1.00 \\
\hline Air Flow supply/exhaust $(\mathbf{l} / \mathbf{s})$ & $45 / 45$ & $45 / 45$ \\
\hline Heat exchanger efficiency $(\%)$ & $87 \%(76 \%)$ & $83 \%(78 \%)$ \\
\hline Thermal bridges $\left(\mathbf{W} / \mathrm{m}^{\circ} \mathbf{C}\right)$ & & \\
\hline Edge beam & 0.094 & 0.17 \\
\hline Corner wall & 0.027 & 0.027 \\
\hline Windows and doors & 0.041 & 0.041 \\
\hline Wall/joist & 0.025 & 0.025 \\
\hline Resulting total loss term $\left(\mathbf{W} /{ }^{\circ} \mathbf{C}\right)$ & 65 & N/A \\
\hline Time constant $(\mathbf{h})$ & 83 & N/A \\
\hline
\end{tabular}

\section{Methodological approach}

The purpose of this paper is to evaluate the performance of the passive houses using a combination of a post-occupancy survey, measurements and validated building energy simulation (IDA Indoor Climate and Energy). The performance of the passive houses has been presented in terms of energy use and average indoor air temperature as well as thermal comfort. The thermal comfort is also evaluated using measurements, a validated CFD model (ANSYS 12) and a standardized post-occupancy survey (the Swedish MM questionnaire) which all the tenants have been asked to fill out after they moved into the buildings. The MM questionnaire is more extensively described in [6], and will be discussed more in detail below. The thermal comfort for the studied passive houses has been also compared with the conventional houses in this recently built area. 


\subsection{Building energy simulation (BES)}

To enable comparisons between survey results, physical measurements, and also to make predictions of consequences of suggested changes, a building energy simulation model was used. In this case IDA Indoor Climate and Energy (ICE) was used, which is a dynamic simulation tool for modeling building performance [7,8]. It is implemented in a general purpose environment (IDA) where all models are available as NMF (Neutral Modeling Format) source code. This model includes simulation of operating temperatures, comfort indices, and daylight levels at arbitrary locations in the zone. The model also has balance equations for $\mathrm{CO}_{2}$, humidity, and energy. The modeling of airflows, thermal conditions, and energy-related problems is a key feature of IDA ICE. The model also contains components for both primary and secondary HVAC systems, i.e., coils, heat exchangers, dampers, fans and boilers, etc. Validation of IDA ICE has been carried out throughout the development where a large number of inter-model comparisons have been made against other programs. An extensive empirical validation exercise based on test cell measurements was also carried out within IEA SH\&C Task 22 (Bring et al., 1999). IDA ICE performed well in this validation [9]. In addition to this, IDA ICE has been validated according to both ASHRAE Standard 140-2004 and CEN Standard EN 15265-2007. The purpose of the model is also to predict energy use, average indoor temperature, and surface temperatures on the inside of the building. The surface temperatures will be used as boundary conditions for the CFD summer and winter case. The reference case is based exclusively on measurements.

\subsubsection{Model descriptions}

The building simulation model (IDA ICE) is an eight-zone model, where the zones have been divided in the same way as for the CFD model presented in Figure 3 below. An overview of the BES model is shown in Figure 2. The heating system is thermostat controlled and gives priority to the heat recovery eXchanger (HRX). The heating system in the reference case is activated when the supply air is below $17^{\circ} \mathrm{C}$. The primary system, in this case district heating, is modeled as a boiler with a maximum power of $2 \mathrm{~kW}$, and a linear temperature distribution from $60^{\circ} \mathrm{C}$ at $25^{\circ} \mathrm{C}$ outside to $20^{\circ} \mathrm{C}$ at $20^{\circ} \mathrm{C}$ outside. The ventilation system is a CAV system and the air flows are presented in Figure 3.

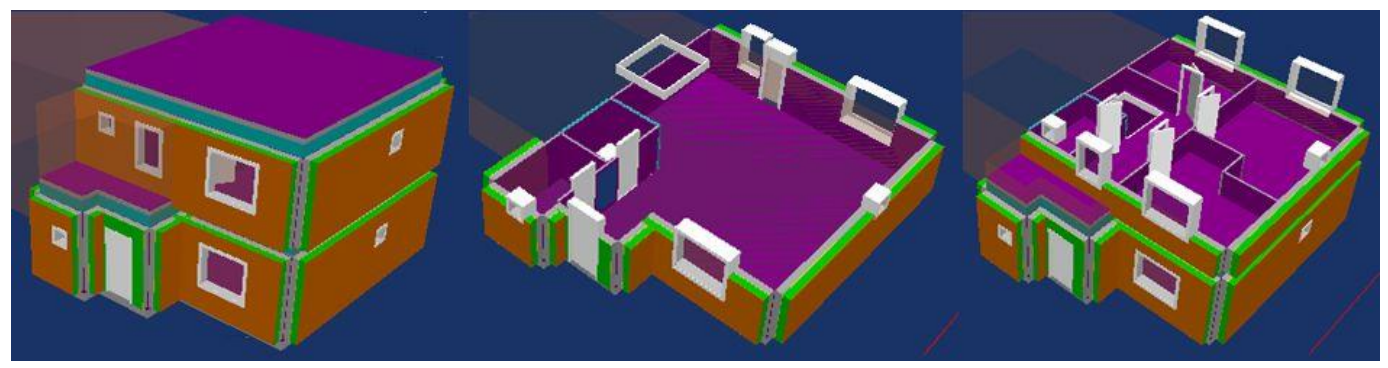

Figure 2. Overview of the BES model implemented in IDA ICE 4. The model is divided in eight zones in two floors.

\subsection{Computational fluid dynamics (CFD)}

Computational Fluid Dynamics (CFD) has been extensively used as a scientific tool in many application and research situations since the 1950s. The use is widespread in many fields, such as aerodynamics, hydraulics, combustion engineering, meteorology, electronic cooling and biomedical engineering, and in predicting both external and internal environment of buildings. The use of CFD to simulate air movements and temperature fields in ventilation applications is also becoming more and more common. One of the earliest publications where CFD was used to 
simulate air flow in rooms was made by Nielsen in 1974. Due to the increase in computer resources, the use of CFD as a scientific tool has increased and continues to increase as it is possible to solve more complex and challenging problems. This method is of special interest for cases where it is not possible to obtain measurements. However, to ensure the validity and reliability of CFD models, measurements are still very much needed. A frequently used approach is to compare results from numerical simulations with measurements; if the results coincide, a numerical approach may be used, which is presented later in this paper.

\subsubsection{Model description}

The modeled building consists of two floors. Air is supplied to bedrooms and living rooms and extracted from bathrooms and kitchen. The boundary conditions in the different cases are shown in Figure 3. The cross section illustrated in the figure represents the analyzed planes later in the paper. The three cases are reference case / winter case / summer case. The boundary conditions and indoor temperatures were gathered when the outdoor temperature was $2^{\circ} \mathrm{C}$. The winter case is based on simulated values from the BES model for a cold day with an outdoor temperature of $13^{\circ} \mathrm{C}$. The corresponding summer case boundary conditions are gathered in the same fashion for a day with an outdoor temperature of $20^{\circ} \mathrm{C}$. These values are typical for winter and summer days in Linköping, Sweden. The direct solar radiation in the model was $29.9 \mathrm{~W} / \mathrm{m}^{2}$ in average during January, and the diffuse part $10.9 \mathrm{~W} / \mathrm{m}^{2}$ during the same time. In summer time direct sunlight was $204.5 \mathrm{~W} / \mathrm{m}^{2}$ on a monthly average with peaks around $950 \mathrm{~W} / \mathrm{m}^{2}$. No shading objects exist in the surroundings. The internal gains are modeled from measurements in the passive house and the resulting load curve is shown in Figure 4. These measurements are reported in [5]. 


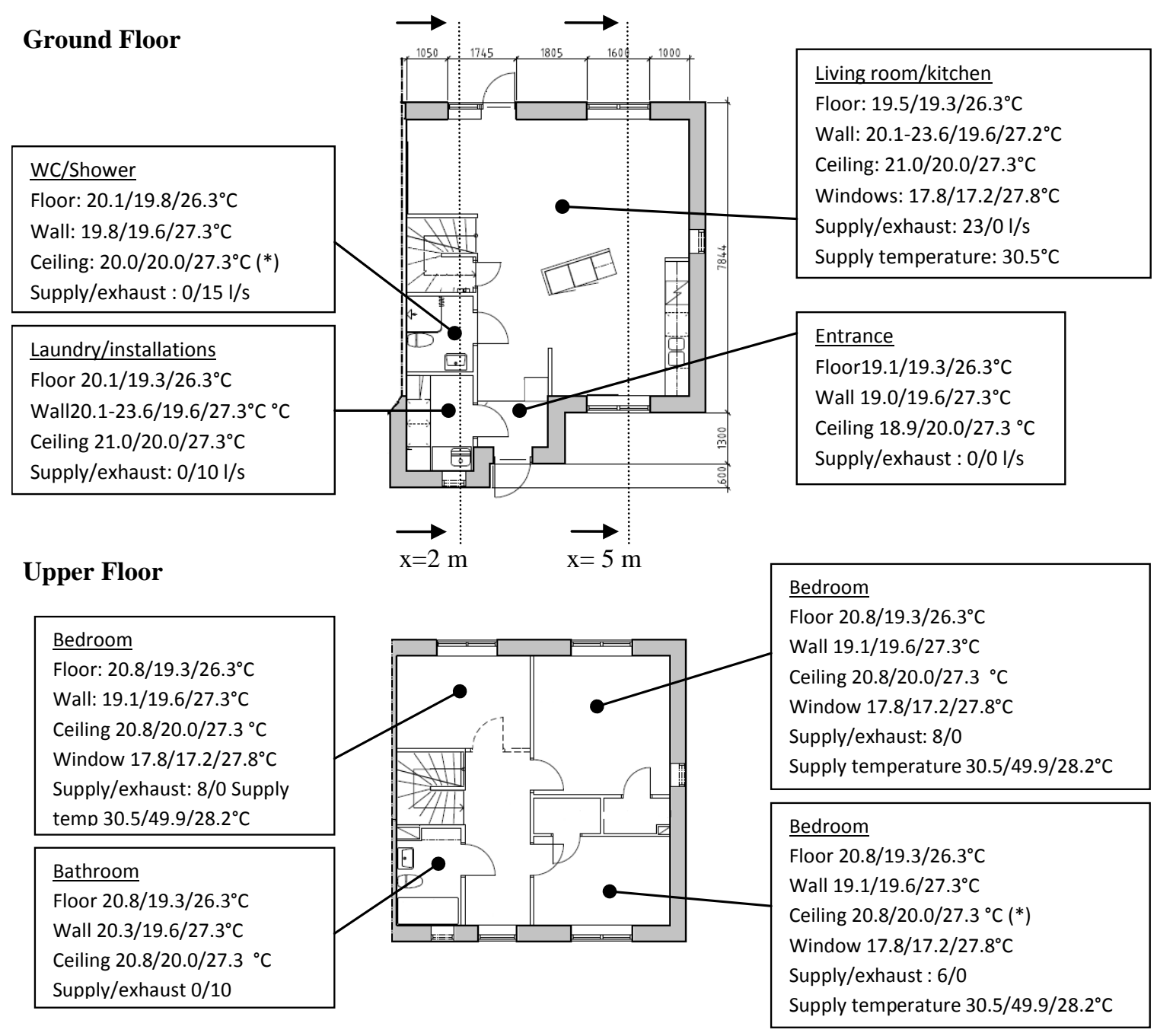

Figure. 3. Physical model and boundary conditions for the passive house. The upper view shows the bottom floor and the lower view the top floor. The temperatures for the different rooms represent validation temperatures/design winter condition/summer condition.

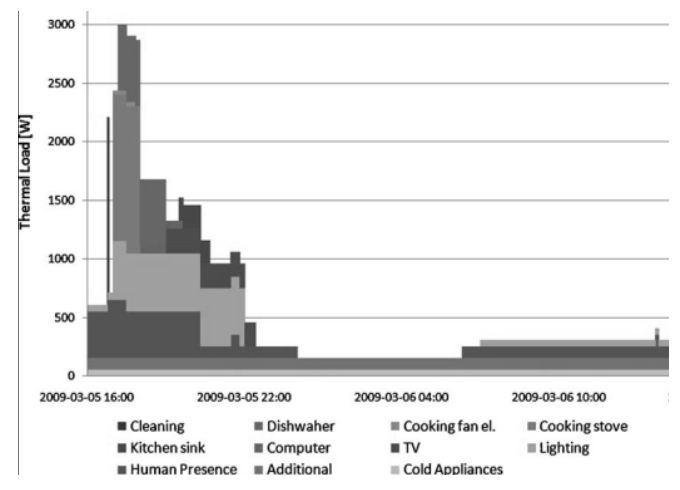

Figure 4. Resulting internal heat gains introduced into the building during the simulation made for comparison [5] 


\subsubsection{Numerical procedure}

ANSYS Workbench 12 with Fluent 12 was used to perform the CFD simulation in the studied cases numerically. The governing equations were solved with a segregated scheme and discretised spatially with a second order upwind scheme. The SIMPLE algorithm solved the coupling between pressure and velocity. The local criterion for numerical convergence, i.e., the maximum relative difference between two consecutive iterations for any local variable, was less than $10^{-4}$ for $p, u, v, w, k$, and $\varepsilon$. For energy the convergence criterion was $10^{-8}$. The RNG k- $\varepsilon$ turbulence model was used for all cases. This was because the turbulence model has been shown to be a robust, well-functioning model in several indoor environment studies when compared to other two-equation models, see e.g. [10, 11, 12].

AirPak was used as a mesher to generate the 3D mesh, after which it was exported to ANSYS/Fluent. The mesh is generated as an unstructured hexahedral mesh. A grid independency study was performed. The present case was simulated with three different grid densities: $1,800,000,3,400,000$ and 4,400,000. The results showed that the differences between the predicted velocities and temperatures were low for the last two grid arrangements. When considering the computer resources, the 3,400,000 structured hexahedral mesh was chosen. The mesh used represents a cell number higher than the minimum recommendation by German guideline VDI 6019. The mesh distribution was controlled by clustering the mesh towards the walls and edges in such a way that the standard wall function was applied properly, i.e., the first numerical point was located at $y^{+}>10$. This choice has been used with good results in e.g $[11,12]$ and is in line with what is found in [13]. The wall boundaries were modelled using the no-slip condition with constant wall temperature. The inlets were modelled with velocity, turbulence intensity, and temperature. In the validation case these parameters were based on measurements in the actual building, while for the winter and summer cases these were based on simulated parameters from IDA ICE.

The option to calculate the comfort indexes needed is not presently included in the CFD code used, making it necessary to implement it using a User Defined Function (UDF) scripting language. The index for Predicted Mean Vote (PMV) and Predicted Percentage Dissatisfied (PPD) based on ISO 7730 was implemented in this fashion. In addition to this, the effectiveness for heat removal and draught rating were implemented using custom field functions [14,17]. The calculation of mean age of air has also been implemented in the code using the UDF interface.

\subsection{Standardized indoor environment questionnaire}

To be able to compare the measured and simulated values with the occupant's perception of the buildings, in terms of indoor environment, a questionnaire approach with complementary interviews was chosen. The MM survey used is an example of a standardized epidemiological survey that has been widely used in Sweden. An epidemiological method is useful for describing the occupants' perceptions and experiences of the indoor environment and can be effective when evaluating the results of e.g. energy efficiency measures [6] or as in this case when comparing indoor environments in two different types of buildings. In literature several different standardized methods are used frequently, e.g. the RSH questionnaire issued by the Building Research Establishment in the United Kingdom, focusing on office environments, and the MM questionnaires, which are often used in the Nordic countries. The first version of this questionnaire was developed in 1986 at the Department of Occupational and Environmental Medicine, Örebro University Hospital [15]. It has been validated as a reliable tool when recognizing indoor environment problems [16], and has been used in a large number of studies. The form has subsections such as: background factors, disturbing environmental factors, 
psychosocial factors at the workplace, prevalence of symptoms among occupants, perception of indoor environment (air temperature, noise, perceived air quality, etc.), and medical history of allergic diseases. In this study the MM survey was used as a post-occupancy evaluation targeting the people who moved into these buildings, both the nine passive houses as well as the 30 more conventional houses. The survey was made during winter 2009-2010. The response rate from the passive houses was $100 \%$ and from the non-passive houses 13 responses were collected from the 30 houses. However, several of the non-passive houses were empty at the time, so the response rate from the non-passive houses actually in use was over $50 \%$.

\section{Post-occupancy evaluation - passive houses vs. conventional houses}

The predictions and measurements are based on a building in the presented area, ie. one of the passive houses. In an attempt to discuss and compare these predictions a post-occupancy evaluation was conducted with the conventional houses in the same built area. The aim of this evaluation was to gather the occupant's perception of the indoor environment, and as method a combination of a standardized questionnaire and interviews was chosen. The same procedure was carried out in both the nine passive houses as well as the 30 non-passive houses that were built in the same area. The resulting responses from the occupants are presented in Figure 5. The dark shaded areas represent the responses from the passive houses and the light shaded areas from the conventional houses.

Too high temperature is reported, and is mainly related to the summer season when adequate ventilation was hard to get according to the respondents. The high level of varying temperature, according to several of the occupants, was a result of not being accustomed to the fact that indoor temperature was so highly affected by internal gains from cooking, showering, etc. One respondent expressed it like this: "The temperature rises when cooking to a much larger degree than normal". Temperature was also reported to be low by several of the respondents, which may be related to the low controller set point, which has later been changed. Stuffy and bad air was reported for both house types, but more often for the passive house.

Another interesting finding was the high levels of complaints of cold floors in the passive house, which is related to the lower floor surface temperature, especially on the ground floor for the passive house. Here the main issues were related to cold tile flooring in the shower room on the first floor as well as in the kitchen area. One of the respondents commented about this: "cold floors all year around".
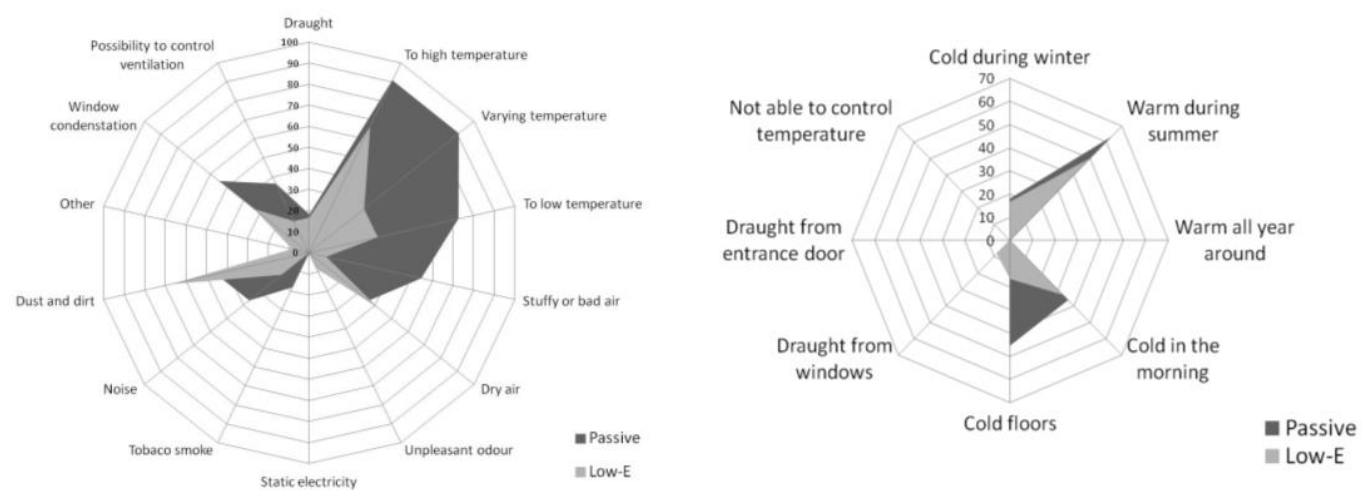
Figure 5. Comparison between responses from the passive houses and the conventional houses as a result of the post-occupancy questionnaire. The results shows high levels of complaints for temperature and cold floors, but low levels for draught, control and unpleasant odors.

\section{Indoor thermal environment - predicted and measured}

The results and discussion will be divided in three themes: (1) temperature; (2) air flow and air velocities; and (3) thermal comfort. The temperature part (1) includes comparing modeled results from both IDA and CFD with measured values as well as discussing the performance of the studied building. The air flow and air velocity part (2) will mainly compare the measured and simulated values for the studied building with both international and national standards. Finally the thermal comfort part (3) will discuss the thermal performance of the studied passive house, by using and comparing with international and national standards. The object of this part is to evaluate the performance of the passive house in terms of thermal comfort.

\subsection{Temperature}

The installed power is $2 \mathrm{~kW}$ or $19 \mathrm{~W} / \mathrm{m}^{2}$ in the passive house, which is higher than the previous Lindås case, $0.9 \mathrm{~kW}$ or $7.5 \mathrm{~W} / \mathrm{m}^{2}$, $[4,18]$ which was the first passive house in Sweden. This enables the users a wider range of indoor air temperatures. The set point for the building systems lets the user set the set point between $18-26^{\circ} \mathrm{C}$. In the measured reference case presented, the set point was $21.4^{\circ} \mathrm{C}$.

An example of a floor supply device in the upper bedroom is shown in Figure 6. A comparison between measurements and CFD is shown as well as the setup during the measurements. The CFD is more buoyance driven than the infrared image close to the supply device, which caused by the simplified inlet device. The results away from the device are in good agreement with measurements.
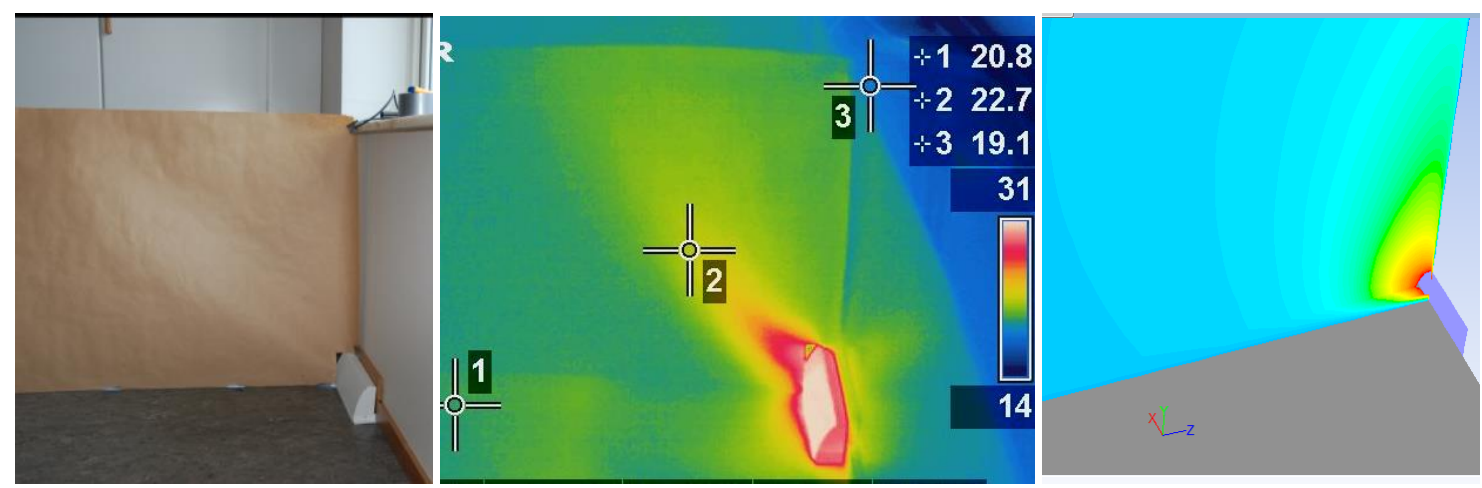

Figure 6. The setup for inlet temperature and distribution measurement (left), IR camera (center) and CFD prediction (right).

The temperature distribution in a cross-section is shown in Figure 7. Temperatures range from $19^{\circ} \mathrm{C}$ at floor level and close to the windows where no hot supply air is added to $20.5^{\circ} \mathrm{C}$ at ceiling level on the second floor. The average difference in temperature between upper and lower floor is about $1^{\circ} \mathrm{C}$. This is also seen in the long-term measurements, and is independent of the set point.

In Figure 8, the air temperature distribution at $0.1 \mathrm{~m}$ above the floor is shown. The air temperature is higher on the second floor at ankle-level. This is mainly a result of active heating on floor level and that the floor doesn't have ground contact as is of interest since the second 
floor to a large part consists of bedrooms. The predicted temperatures for the validation case range from $19.1{ }^{\circ} \mathrm{C}-21.0^{\circ} \mathrm{C}$ when not close to the supply devices.

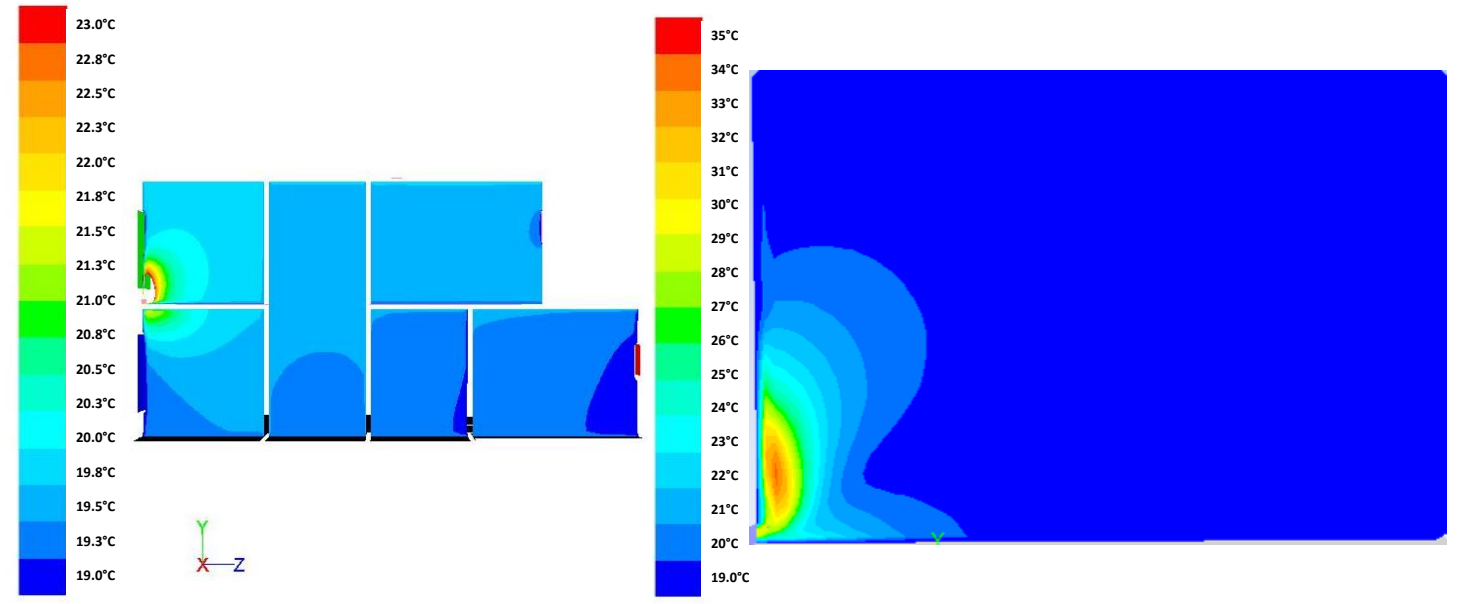

Figure 7. Air temperature profiles for two cross sections in the building $(x=2 \mathrm{~m})$ and a cross-section of the bedroom at $(\mathrm{x}=5.5 \mathrm{~m})$. Temperatures range from $19^{\circ} \mathrm{C}$ at floor level and close to the windows where no hot supply air is added to $20.5^{\circ} \mathrm{C}$ at ceiling level on the second floor. The average difference in air temperature between upper and lower floor is about $1^{\circ} \mathrm{C}$.

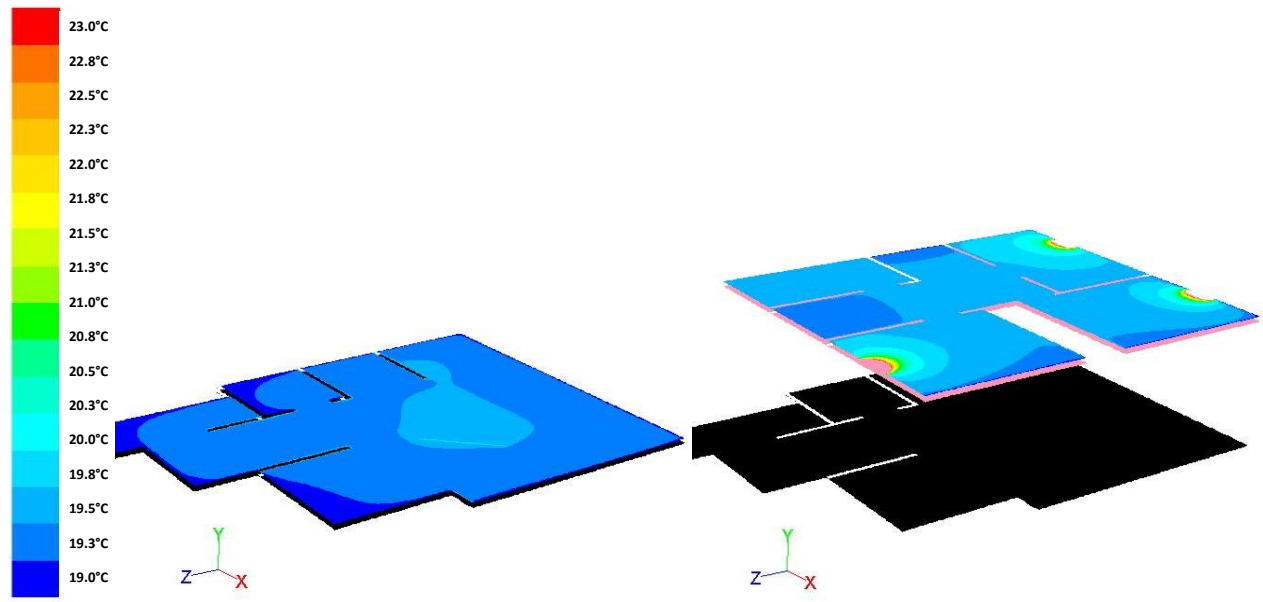

Figure 8. Predicted air temperatures $0.1 \mathrm{~m}$ above floor on ground floor (left) and top floor (right). The temperature is higher on the second floor. This is mainly a result of active heating on floor level. The predicted air temperatures for the validation case range from $19.1^{\circ} \mathrm{C}-21.0^{\circ} \mathrm{C}$ when not close to the supply devices.

\subsection{Air flows and air velocities}

According to EN 15251 [19], ventilation rates are divided into four categories, in a similar way as for thermal comfort which is presented in Table 2. The corresponding values are further divided into three parts depending on the amount of pollution that is expected from building materials and people. For a residential building with continuous operation and where complete mixing can be assumed the following values are recommended, see Table 2 . 
Table 2. Recommended air flows for residential buildings with continuous operation. (EN 15251)

\begin{tabular}{|c|c|c|c|c|c|c|}
\hline \multirow[b]{2}{*}{ Category } & \multicolumn{2}{|l|}{ Supply air flow } & & \multicolumn{2}{|c|}{ Exhaust air flow } & \multirow[b]{2}{*}{ Toilets } \\
\hline & air change rate & $\begin{array}{l}\text { Living rooms } \\
\text { and bed rooms }\end{array}$ & & Kitchen & Bathroom & \\
\hline & I/s.m2 & I/s.pers & I/s.m2 & $1 / \mathrm{s}$ & $1 / \mathrm{s}$ & $\mathrm{I} / \mathrm{s}$ \\
\hline I & 0.49 & 10 & 1.4 & 28 & 20 & 14 \\
\hline II & 0.42 & 7 & 1 & 20 & 15 & 10 \\
\hline III & 0.35 & 4 & 0.6 & 14 & 10 & 7 \\
\hline IV & $<0.35$ & $<4$ & $<0.6$ & $<14$ & $<10$ & $<7$ \\
\hline
\end{tabular}

The studied building fulfills category II according to this classification, as the average air change rate is $0.43 \mathrm{l} / \mathrm{s} \cdot \mathrm{m}^{2}$. This is considered normal for new buildings according to EN 15251 and also by the Swedish building code. The air flows in the upper bathrooms, however, fall into category III as well as the largest bedroom if this is used by two persons.

The air velocities in the buildings are generally low, in the occupied zone below $0.1 \mathrm{~m} / \mathrm{s}$. A velocity plot from the CFD simulation is presented in Figure 9. The resulting velocity profile only exceeds $0.15 \mathrm{~m} / \mathrm{s}$ close to the supply devices on the top floor in the bedrooms, and a ceiling level in the living room on the bottom floor. However, it is important to note that this is in general heated air, for which reason draught problems are less likely to be a problem. The Draught Rating (DR), according to [17], for the different zones are presented in Figure 13 and discussed more extensively below.

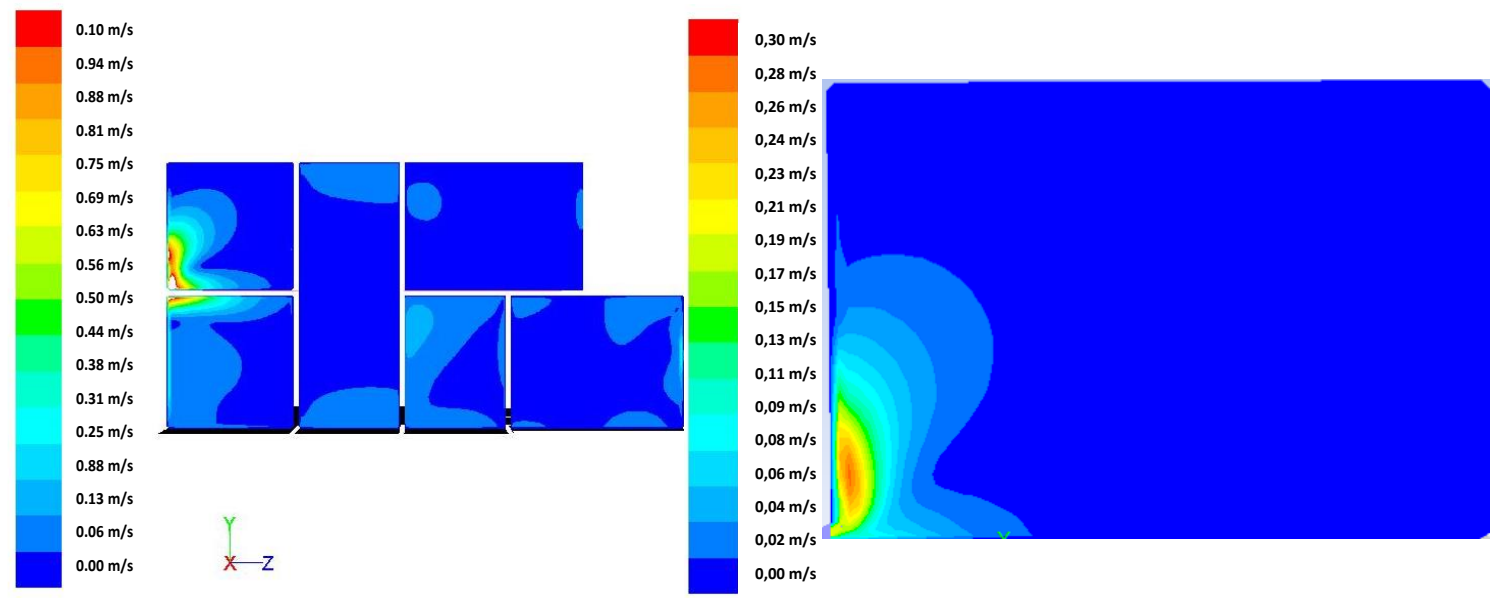

Figure 9. Velocity profiles for two cross sections in the building $(x=2 \mathrm{~m})$ and a cross-section of the bedroom at $(x=5 \mathrm{~m})$. In general low velocities except in proximity of the supply devices. Velocities in the occupied zone are in general below $0.1 \mathrm{~m} / \mathrm{s}$.

\subsection{Thermal comfort}

To relate the physical parameters of temperature, velocity, and radiation to thermal comfort, the method recommended in ISO 7730 using Predicted Mean Vote (PMV) and Predicted Percentage Dissatisfied (PPD) has been used. In addition to this, recommended classifications in EN 15251 
for thermal comfort have been used. The categories from the standard are presented in Table 3, and divide buildings into four categories depending on PMV and PPD values.

The PMV for the studied building is presented in Figure 10. The values during winter are typically peaking daily at around -0.4 for PMV during the heating season and 0.5 during summer. This results in a PPD value below $10 \%$ during heating season and slightly higher during summer. Some peaks are found in the PMV/PPD during summer, and this is connected to days with large amounts of sunlight, and no free cooling using windows or openings. The overall performance of the building, in terms of thermal comfort, during this year can thus be classified as a category II in the EN 15251 system, where PPD is less than 10\%. The distribution of hours in the different categories is presented in Figure 11. The distribution shown is calculated for 1.2 Met and a range for Clo of $0.9 \pm 0.4$. The model chooses a clothing level within set limits to give reasonable predictions of an adaptive clothing level.
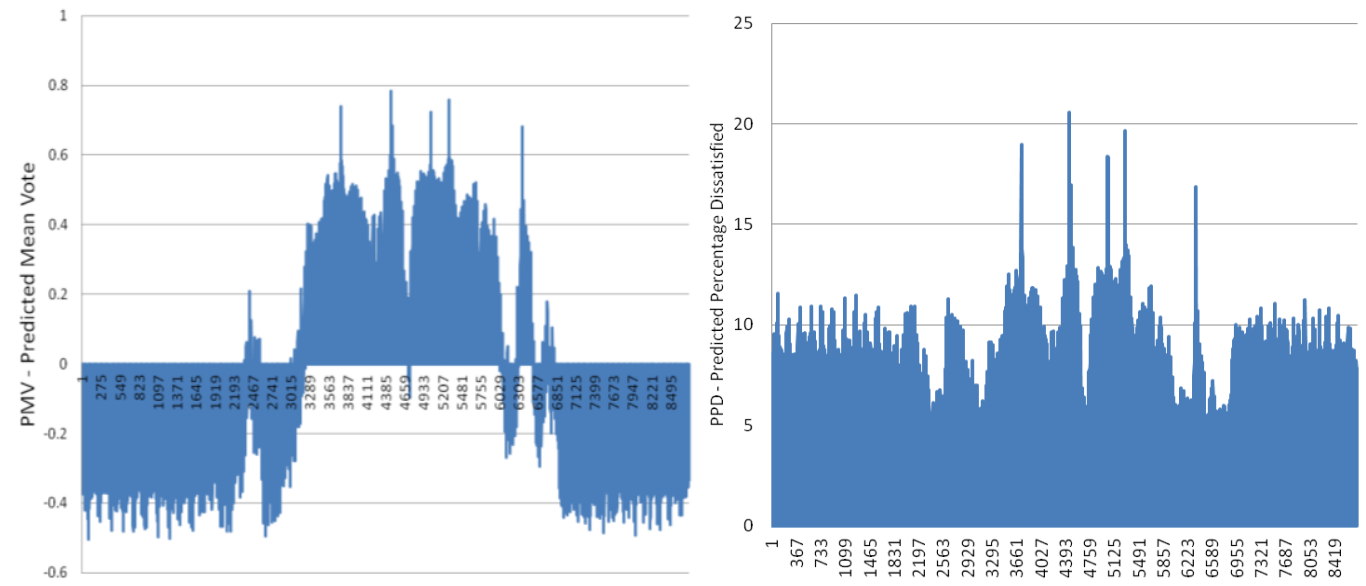

Figure 10. Left figure shows the distribution of PMV over the year, indicating slightly cold sensation during the heating season and a slightly warm period during the warmer part of the year. The resulting PPD is shown in the right figure, indicating a predicted percentage of dissatisfied of about $10 \%$.

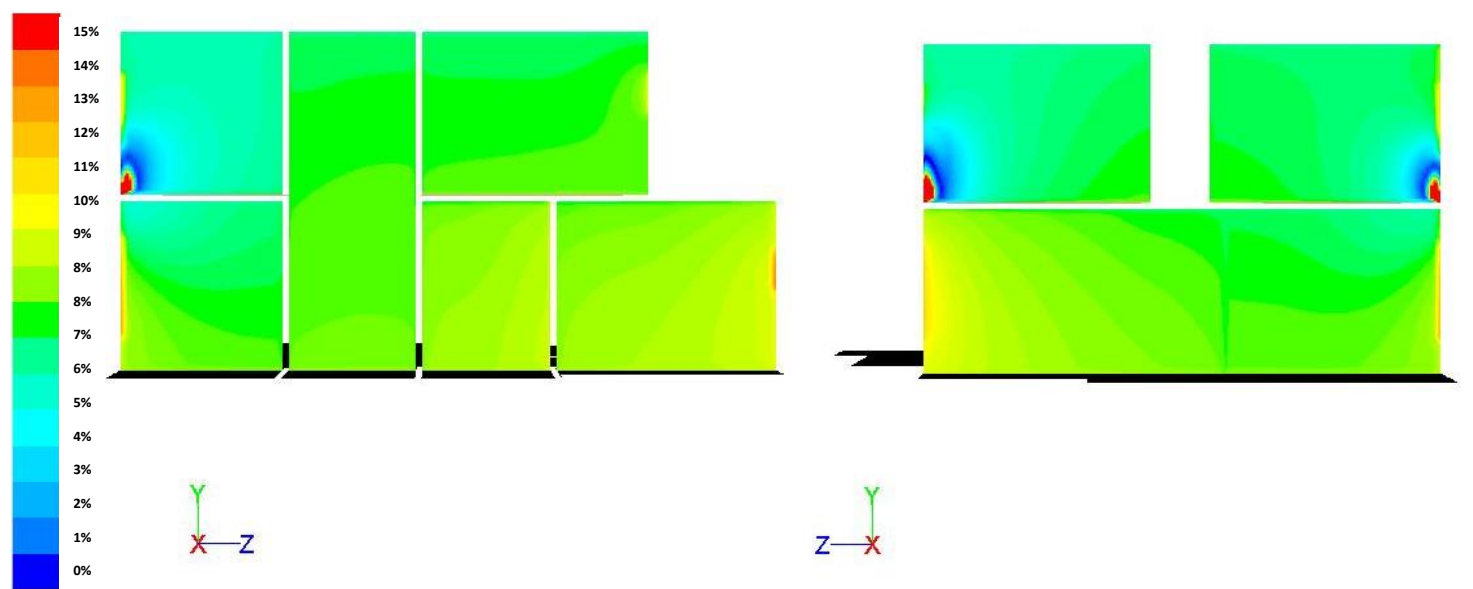

Figure 11. Spatial distribution of PPD in the reference model. The predictions show less than $15 \%$ dissatisfied in the entire volume except when close to the supply device, where heat is supplied. The average in the occupied zone is $11 \%$.

The spatial distribution of PMV/PPD has also been investigated for the reference case using CFD. The PMV/PPD model has been implemented in the CFD code using a user-defined function, as is not included in the original code. This implementation has been used in other publications such as 
[11]. In Figure 11 the resulting spatial distribution of PPD is shown. The values range from 13\% dissatisfied in the entrance part of the building to below 10\% in the bedroom areas on the top floor. The plots shown are made for 1.2 Met and 1.1 Clo. When using the classification from EN 15251, presented in Table 3, the building has a range of hours in the four different categories. The distribution between these categories is dependent on indoor temperature set point, which is why it is arguably of interest to present comfort as a function of this set point. For the passive house this is presented in Figure 12, showing that the predicted number of hours in type IV is above $20 \%$ for a set point of $18^{\circ} \mathrm{C}, 18 \%$ for $20^{\circ} \mathrm{C}$ and about $1 \%$ for $21.4^{\circ} \mathrm{C}$. The set point $21.4^{\circ} \mathrm{C}$ was used during the initial part of the measurements in all houses. The comfort increases when increasing set point in the building. For a set point of $26^{\circ} \mathrm{C}$ the number of hours in category IV starts to increase due to over-heating during spring and autumn. While the comfort increases with increasing set point, so does energy use. The energy use for the buildings will be discussed further below. In addition to the overall comfort there are two local sources of discomfort of interest for this type of building, (1) draught and (2) cold floors.

Table 3. Description of the applicability of the thermal comfort categories according to the standard (EN EN 15251, p. 13, p. 25)

\begin{tabular}{|c|c|c|c|}
\hline Category & Explanation & PPD & PMV \\
\hline I & $\begin{array}{l}\text { "High levels of expectation and is recommended for spaces } \\
\text { occupied by very sensitive and fragile persons with special } \\
\text { requirements like handicapped, sick, very young children and } \\
\text { elderly persons" }\end{array}$ & $<6 \%$ & $-0.2<\mathrm{PMV}<0.2$ \\
\hline II & $\begin{array}{l}\text { "Normal level of expectation and should be used for new } \\
\text { buildings and renovation" }\end{array}$ & $<10 \%$ & $-0.5<P M V<0.5$ \\
\hline III & $\begin{array}{l}\text { "Acceptable, moderate level of expectation and may be used for } \\
\text { existing buildings" }\end{array}$ & $<15 \%$ & $-0.7<\mathrm{PMV}<0.7$ \\
\hline IV & $\begin{array}{l}\text { "Values outside the criteria for the above categories. This } \\
\text { category should only be acceptable for a limited part of the year" }\end{array}$ & $>15 \%$ & $P M V<-0.7$ or $\mathrm{PMV}>0.7$ \\
\hline
\end{tabular}

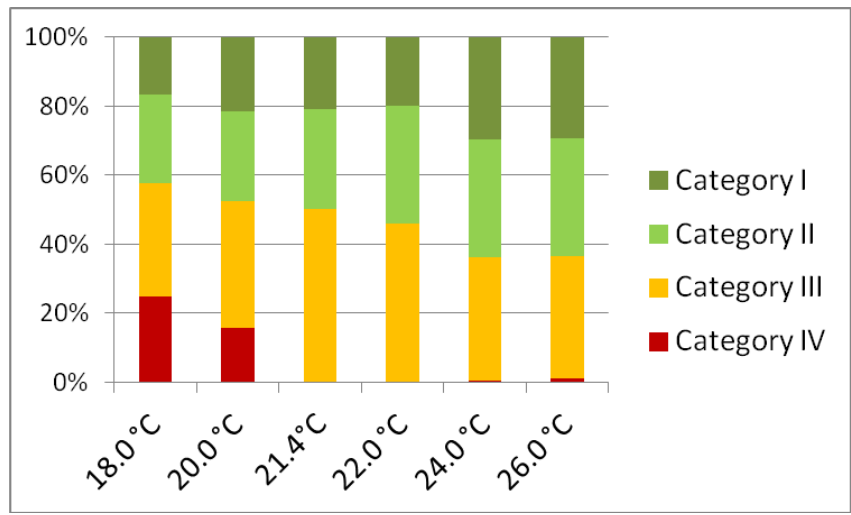

Figure 12. Percentage of hours in different categories according to the criteria in EN 15251:2007 for the passive house as a function of controller set point. The reference set point was $21.4{ }^{\circ} \mathrm{C}$, which was used during the initial measurements.

\subsection{Draught}

To relate the physical parameters to the risk of draught in the building, the draught rating (DR) presented in [17] has been used. The draught rating is defined as: 
where $\mathrm{T}$ is local mean air temperature $\left({ }^{\circ} \mathrm{C}\right), \mathrm{V}$ local mean air velocity $(\mathrm{m} / \mathrm{s})$ and TI local turbulence intensity (\%). In Figure 13 the distribution of DR is shown. Low values of DR are predicted in the entire zone, less than $10 \%$. Close to the supply device the heated air increases the DR slightly and this is the reason for a local minimum after entering the zone. This indicates that there is a low risk of draught in these buildings, during winter conditions.
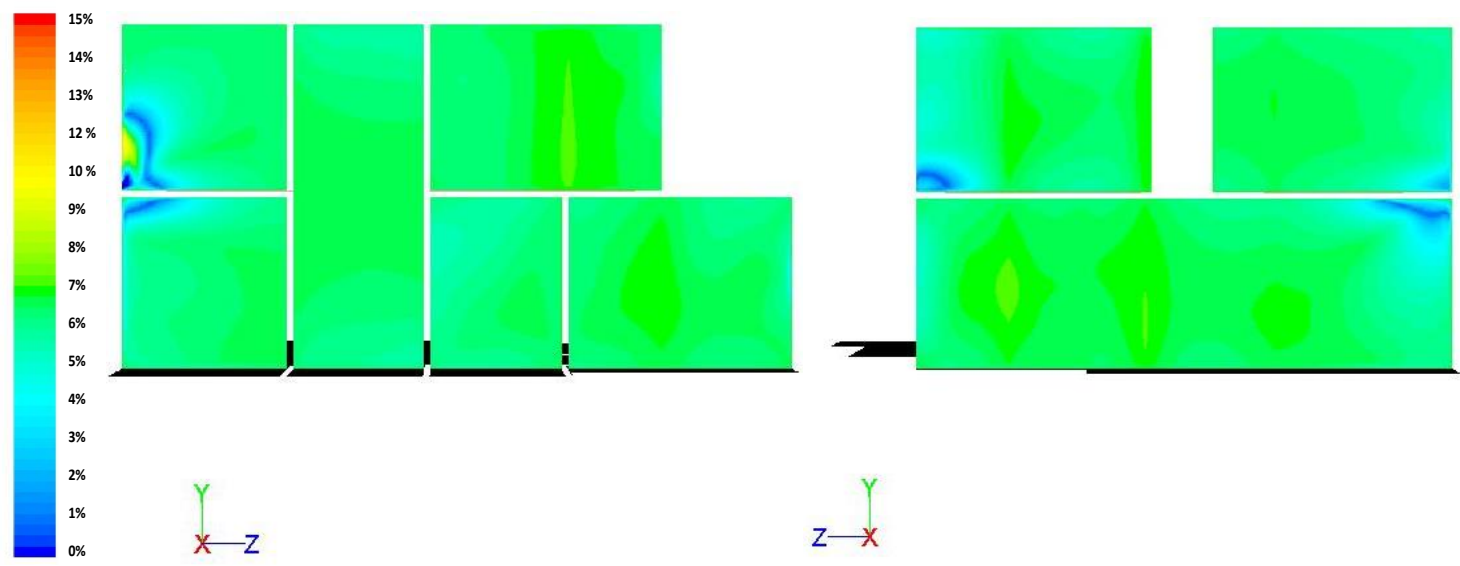

Figure 13. Spatial distribution of draught rating. The values do not exceed $10 \%$, indicating a low risk of draught problems in the studied building.

\subsection{Cold floors}

One of the interesting parameters when investigating low energy buildings and passive houses, with air heating, is the floor temperature. This because when the radiators, which are commonly used, are removed, the contribution from radiation decreases, thereby increasing the risk of low floor surface temperatures. To relate the temperature of the floor to a number of people predicted to be dissatisfied, the equation presented in ISO $7730, \mathrm{PD}_{\text {floor }}$ has been used. The $\mathrm{PD}_{\text {floor }}$ equation is defined as:

$$
P D_{\text {floor }}=100-94 \cdot e^{\left(-1.387+0.118 T_{\text {foor }}-0.0025 T_{\text {foor }}{ }^{2}\right)} \text {. }
$$

This equation is valid for people wearing light shoes or similar. Similar values may be used for people sitting or lying on the floor (ISO 7730). The $\mathrm{PD}_{\text {floor }}$ has been derived using non-linear regression analysis. For spaces where people are expected to be barefoot, recommendations are given in ISO/TS 13732-2 [20].

The resulting predictions of $\mathrm{PD}_{\text {floor }}$ are shown in Figure 14 along with surface temperature and outdoor temperature for the studied case. The floor temperature is about $19.5^{\circ} \mathrm{C}$ during the heating season and higher during summer, resulting in about $10 \%$ dissatisfied during the heating season and a slightly lower number during summer. These predictions show no general problem with floor temperature for people wearing footwear.

However, for bathrooms and bedrooms where people are expected to be without footwear recommendations are given in ISO/TS 13732-2 [20]. This technical specification summarizes human contact with surfaces at moderate temperatures. This technical specification recommends an optimum floor temperature for the materials present in bedroom (linoleum floor covering) of $26^{\circ} \mathrm{C}$ for long-term presence (more than $10 \mathrm{~min}$ ) and for the bathrooms (tile) $28.5^{\circ} \mathrm{C}$. The $15 \%$ dissatisfied limit for the linoleum floor covering is $24-32^{\circ} \mathrm{C}$, and $27.5-29^{\circ} \mathrm{C}$ for the tile flooring. 
So from this perspective the floor temperatures can be expected to result in complaints from the occupants. This is further discussed in the port-occupancy evaluation.

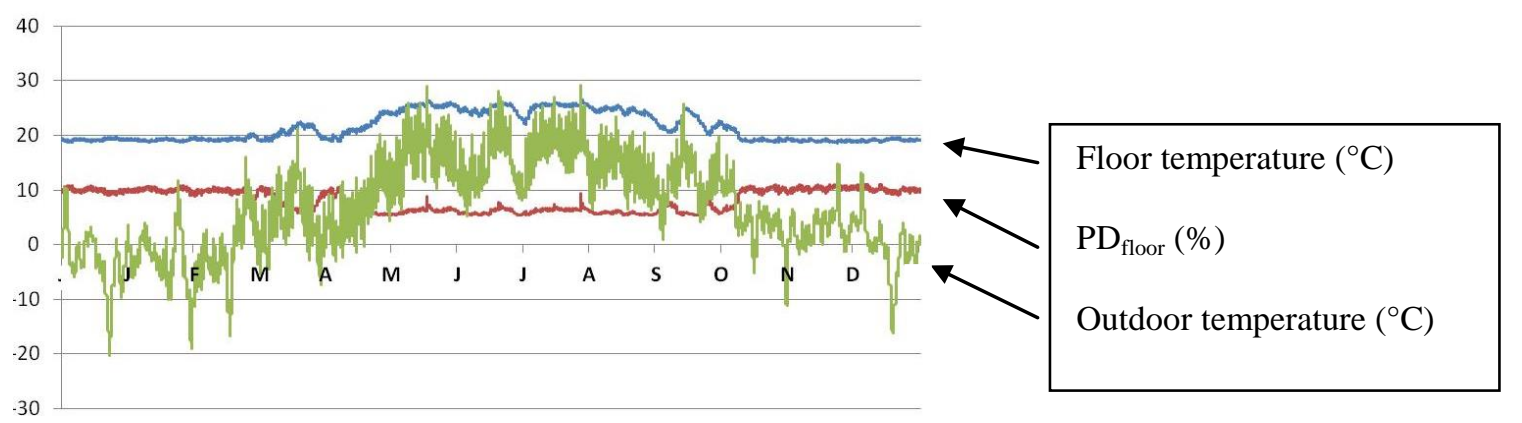

Figure 14. Simulated floor temperature (IDA ICE) and the corresponding predicted percentage of dissatisfied as a result of this floor temperature according to ISO 7730. The results are relevant for predictions of effects of floor temperatures when occupants are wearing socks or footwear.

\section{Energy use predicted and measured}

The modeled energy use has been compared with measurements to validate the IDA ICE model. The comparison is reported in [5] where an extensive validation procedure was carried out. The predictions generally under-predict the actual demand all months except April. In [5], a parametric study was also performed in an attempt to show possible improvements to the building structure, but the effect on indoor environment was not extensively studied.

The energy use in the studied buildings is highly affected by both the structure and amount of internal gains, which was also shown in [18] in the Lindås passive houses, as well as by the choice of set point in the houses. The results reported above are based on a set point of $21.4^{\circ} \mathrm{C}$ which was used initially in the buildings when the study and post-occupancy evaluation was performed. The occupants currently have the possibility to change this set point, which is also reflected in the indoor temperature logged in the test building. The impact of this choice of set point is shown in Figure 15.

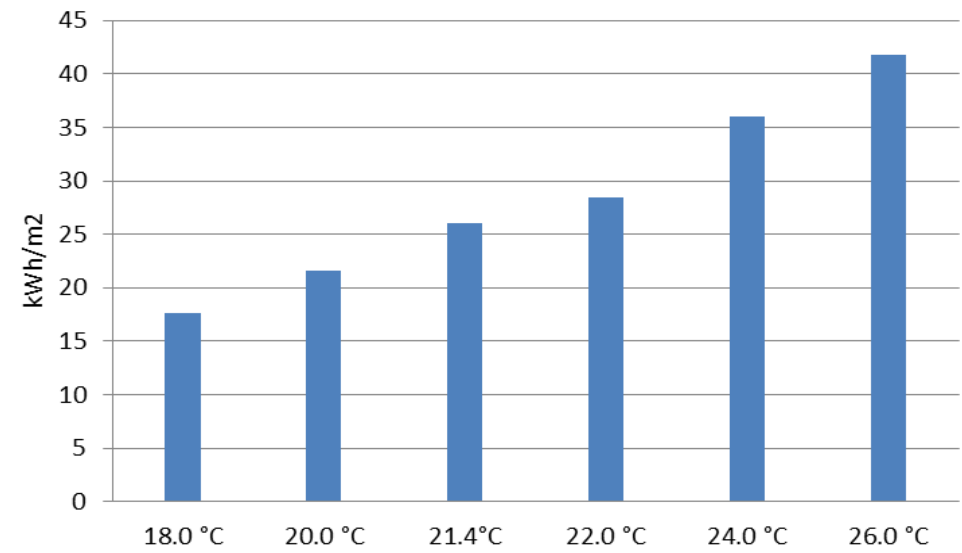

Figure 15. Presentation of energy use as a function of set point for the studied passive house. 


\section{Concluding discussion}

This paper presents the performance of 9 passive houses built in Linköping, Sweden, using a combination of a post-occupancy survey, measurements and validated building energy simulation (IDA Indoor Climate and Energy). The performance of the passive houses has been discussed in terms of energy use and thermal comfort as well as local comfort using cold floor temperature and risk of draught. In addition, the thermal comfort for the studied passive houses has been also compared with the conventional houses built in the same area.

The built area consists of 39 newly constructed terraced houses, of which nine are built according to the Swedish interpretation of the passive house standard issued by FEBY. The buildings are rental houses and equipped with a total heating power of $20 \mathrm{~W} / \mathrm{m}^{2}$ which is slightly higher than the recommendations by FEBY $\left(12 \mathrm{~W} / \mathrm{m}^{2}\right)$ and compared to Lindås $\left(8 \mathrm{~W} / \mathrm{m}^{2}\right)$ which was the first passive house project in Sweden. Another aspect that makes the buildings unique in Sweden is the fact that they use district heating, even though the maximum power and total energy use is low.

The indoor thermal comfort for these newly built passive houses is found to be generally good based on the measurements and predictions presented in this paper. However, some interesting findings related to local comfort such as cold floors are found in the post-occupancy evaluation as well as in the predictions. In addition, it was shown in the post-occupancy evaluation that there is a higher degree of complaints related to high temperatures during summer in the passive houses. The buildings do not have external shading installed by default. The effect of varying temperatures was also observed in the passive houses to a higher degree than in the more conventional buildings, especially related to cooking and other heat-generating activities, which is normal in a well-insulated and airtight building.

The energy use for these buildings is in line with the predictions, but is as shown highly dependent on set point, which of course is expected. A trend of increasing set points was also seen, which simply reflects the fact that the people living in the buildings are trying to optimize their comfort. Set points of $22-23^{\circ} \mathrm{C}$ were common after people have lived in the building for a year. For a $20^{\circ} \mathrm{C}$ set point the specific annual energy use for heating is around $21 \mathrm{kWh} / \mathrm{m}^{2} . \mathrm{y}$, while it is about $35 \mathrm{kWh} / \mathrm{m}^{2}$.y for a $24^{\circ} \mathrm{C}$ set point. The overall performance of $21 \mathrm{kWh} / \mathrm{m}^{2}$.y is thus found to meet the passive house design values for energy use, which is $21 \mathrm{kWh} / \mathrm{m}^{2} . \mathrm{y}$ according to FEBY (FEBY, 2009).

\section{Acknowledgements}

The authors would like to thank Professor Jenny Palm at Linköping University for her guidance and the AES program, Swedish Energy Agency, for financial support. In addition to this we would also like to thank Mr Theodor Hovenberg and Mr Per Carlfjord at Stångåstaden $\mathrm{AB}$, the company that built the houses, as well as Dr Wiktoria Glad, Mr Jakob Rosenqvist, and Mrs Jessica Rahm, Linköping University, for valuable support and discussions.

\section{References}

[1] Feist, W., Schnieders, J., Dorer, V., Haas, A., (2005) Re-inventing air heating: convenient and comfortable within the frame of the Passive House concept, Energy and Buildings 37 (11) 11861203 
[2] Forum for energy efficient buildings (FEBY) (2009), Specification for passive houses (Swedish: Kravspecifikation för Passivhus) (2009), Swedish Environmental Institute Report No. A1592.

[3] Wall, M. (2006). Energy-efficient terrace houses in Sweden - Simulations and measurements, In: Energy and Buildings, 38 (6): JUN 627-634.

[4] Karlsson, F., Moshfegh, B. (2006) Energy demand and indoor climate in a low energy building-changed control strategies and boundary conditions, In: Energy and Buildings, 38 (4): APR 315-326.

[5] Molin, A., Rohdin, P., Moshfegh, B., (2011) Investigation of energy performance of newly built low-energy buildings in Sweden, Energy and Buildings 43, pp. 2822-2831.

[6] Andersson, K., (1998)Epidemiological Approach to Indoor Air Problems, Indoor Air; 4: 3239.

[7] Björsell, N., Bring, A., Eriksson, L., Grozman, P., Lindgren, M., Sahlin, P., Shapovalov, A., Vuolle, M., (1999) IDA Indoor Climate and Energy. Proceedings of the 6th International IBPSA Conference, Kyoto.

[8] Vuolle, M., (1999) An NMF based model library for building thermal simulation. Proceedings of the 6th International IBPSA Conference. Kyoto.

[9] Bring, A., Sahlin, P., Vuolle, M., (1999) Models for Building Indoor Climate and Energy Simulations. Report of IEA Task 22. (http://www.equa.se/dncenter/T22Brep.pdf).

[10] Chen, Q., (2009) Ventilation performance prediction for buildings: A method overview and recent applications, Building and environment 44 (4), pp. 848-858.

[11] Rohdin, P., Moshfegh, B., (2011) Numerical modeling of indoor climate and air quality in industrial environments - A comparison between different turbulence models and supply systems supported by field measurements, Building and Environment 46 (11) 2011, pp. 2365-2374.

[12] Rohdin, P., Moshfegh, B., (2007) Numerical Predictions of Indoor Climate in Large Industrial Premises - A comparison between different k- $\varepsilon$ models supported by field measurements, Building and Environment 42 pp.3872-3888.

[13] - Chen, Q., (1995) Comparison of different k-e models for indoor air flow computations, Numerical heat transfer 28 (3): pp. 353-369.

[14] ISO (2005), Ergonomics of the thermal environment - Analytical determination and interpretation of thermal comfort using calculations of the PMV and the PPD indices and local comfort criteria, ISO 7730:2005 Geneva: International Standard Organization.

[15] Anderson, K., Stridh, G., Fagerlund, I., Larsson, B., (1993) The MM-questionnaire - A Tool when Solving lndoor Climate Problems, Orebro, Sweden, Department of Occupational and Environmental Medicine. 
[16] Sundell, J., Anderson, B., Andersson, K. and Lindvall, T. (1993) "Volatile organic compounds in ventilating air in buildings at different sampling points in the buildings and their relationship with the prevalence of occupant symptoms", Indoor Air, 3, 82-93.

[17] Awbi, H., (2003) Ventilation of buildings, 2ed, Spon press.

[18] Karlsson, F., Rohdin, P., Persson, M-L. (2007). Measured and predicted energy demand of a low energy building: Important aspects when using building energy simulation, In: Building Services Engineering Research and Technology, 28 (3): 223-235.

[19] EN, (2007) Indoor environment input parameters for design and assessment of energy performance of buildings addressing indoor air quality, thermal environment, lighting and acoustics, EN 15251:2007.

[20] ISO/TS (2001), Economics of the thermal environment - methods for the assessment of human response to contact with surfaces: Part 2 - Human contact with surfaces at moderate temperature, ISO/TS 13732-2 Technical Specification: Geneva. 